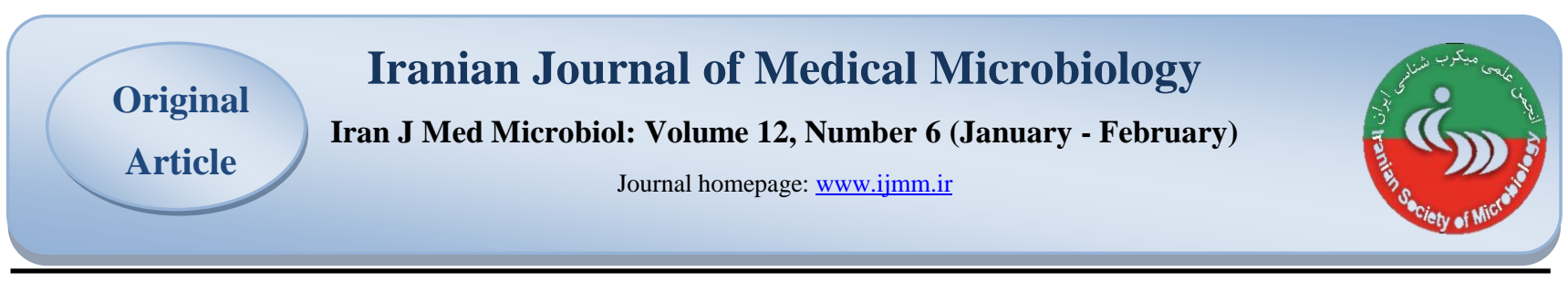

\title{
Prevalence of Mycoplasma pneumonia in Patients with Respiratory Infections from Shaheed Mostafa Khomeini and Khatam Hospitals by Culture and PCR Methods
}

\author{
Iman Pouladi' ${ }^{1}$, Mohsen Taheri $^{1}$, Mohammad Niakan $^{1 *}, \operatorname{Reza}^{*}$ Mirnejad $^{2}$, Ghasem Azimi $^{3}$
}

1. Department of Microbiology, Medicine Faculty, Shahed University, Tehran, Iran

2. Molecular Biology Research Center, Systems Biology and Poisonings Institute, Baqiyatallah University of Medical Sciences, Tehran, Iran

3. Departement of Internal Diseases, Shahid Mostafa Khomeni Hospital, Tehran, Iran

\section{Article Information}

\section{Article history:}

Received: 2018/05/21

Accepted: 2019/01/22

Available online: 2019/03/06

Article Subject:

Medical Bacteriology

IJMM 2019; 12(6): 382-389

Corresponding author:

\section{Mohammad Niakan}

Department of Microbiology,

Medicine Faculty, Shahed

University, Tehran, Iran

Email:

niakan@shahed.ac.ir

Use your device to scan and read the article online

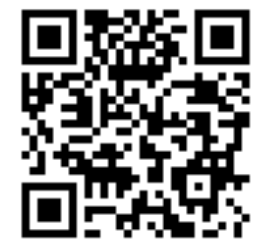

\section{Abstract}

Background and Aims: Mycoplasma pneumoniae is one of the most important pathogens causing human respiratory tract infection; especially in community-acquired pneumonia (responsible for $10-40 \%$ of these infections). The aim of this study was to evaluate the prevalence of Mycoplasma pneumonia in patients with respiratory infections from Mostafa Khomeini and Khatam hospitals, by culture and molecular methods.

Materials and Methods: In this study, 100 samples of throat swab from patients with respiratory infections were collected. All samples were cultured in PPLO broth and PPLO agar. After culture and genomic DNA extraction, PCR was carried out using specific M. pneumoniae primers.

Results: In this study, 14 (14\%) colonies of Mycoplasma were isolated on PPLO agar medium. Using specific primers, 17 samples (17\%) were detected as Mycoplasma genus and 6 samples $(6 \%)$ were confirmed to be $M$. pneumoniae species.

Conclusions: Based on the results of this study, For the detection of $M$. pneumoniae among the respiratory infections cases PCR is a highly reliable and sensitive method compared to the culture media. Using specific primers, PCR can confidently detect and separate infectious agents even in the genesis and species level.

Keywords: Mycoplasma pneumonia, Polymerase chain reactions, Culture, Respiratory infections

Copyright ( 2019 , Iran J Med Microbiol This is an open-access article distributed under the terms of the Creative Commons Attribution-noncommercial 4.0 International License which permits copy and redistribute the material just in noncommercial usages, provided the original work is properly cited.

\section{How to cite this:}

Pouladi I, Taheri M, Niakan M, Mirnejad R, Azimi G. Prevalence of Mycoplasma pneumonia in Patients with Respiratory Infections from Mostafa Khomeini and Khatam Hospitals by Culture and PCR Methods . Iran J Med Microbiol. 2019; 12 (6) :382-389 


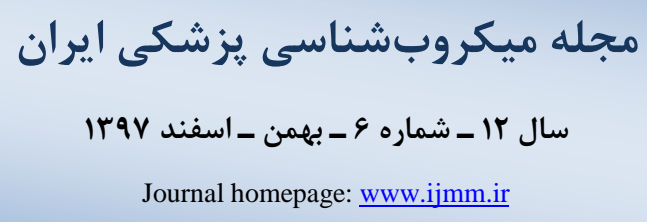

\title{
فراوانى مايكويلاسما ينومونيه در بيماران مبتلا به عفونتهاى تنفسى مراجعهكنتده به بيمارستانهاى مصطفى خمينى(ره) و خاتمالانبيا به روشهاى كشت و PCR
} ايمان يولادى'، محسن طاهرى'، محمد نياكان "'، رضا ميرنزاد'، قاسم عظيمى"

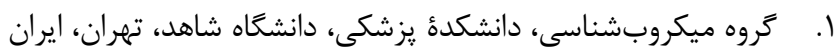

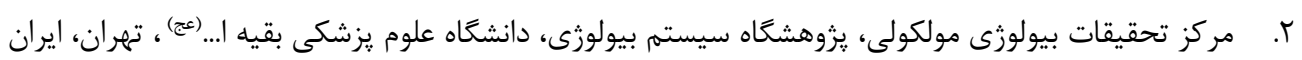

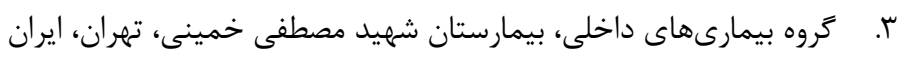

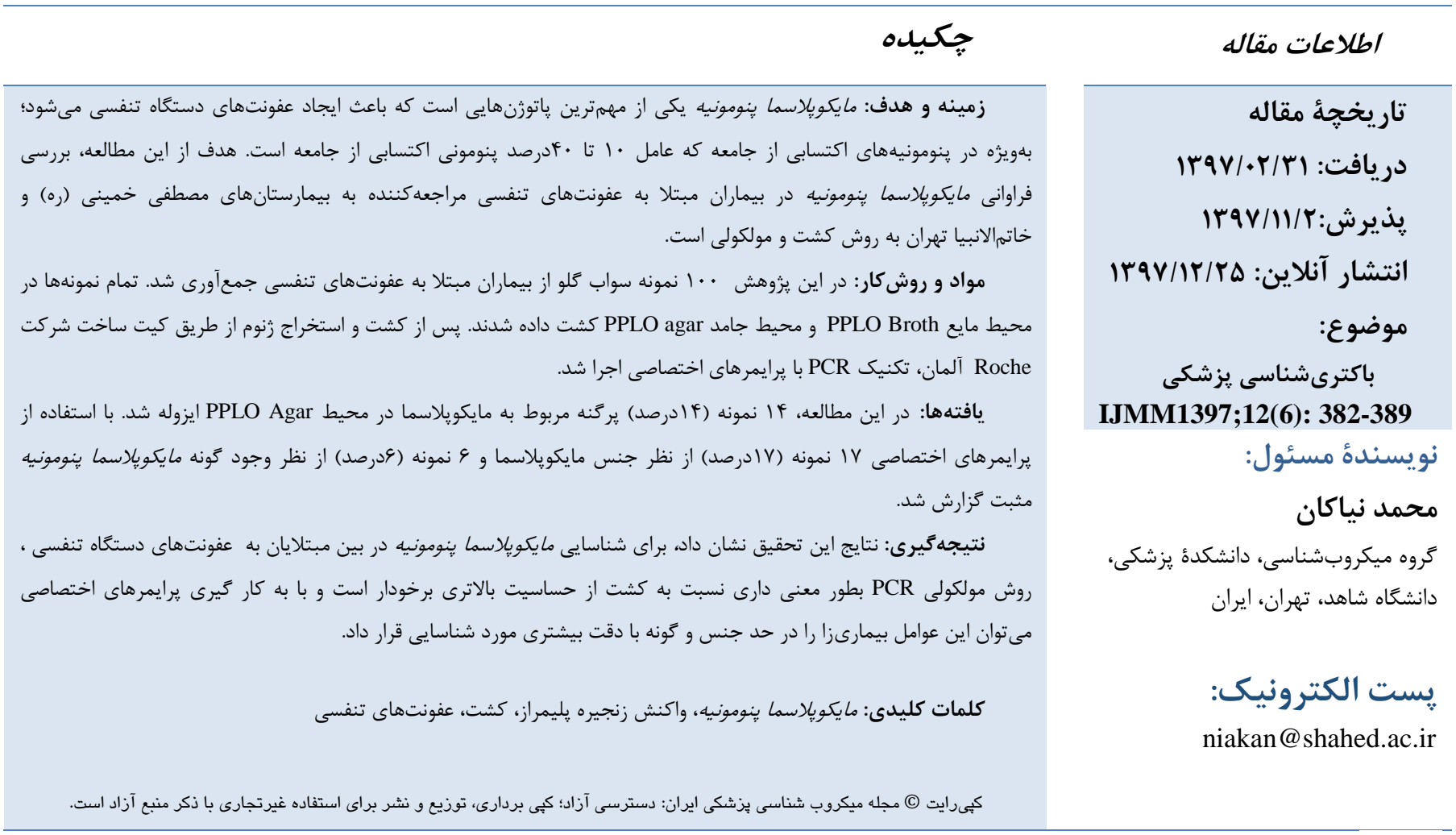

مقلدمه

خستخى و بدحالى ممكن است در افراد وجود داشته باشد و كَته

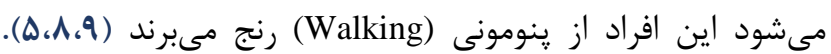

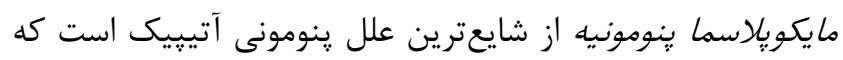

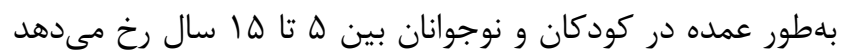

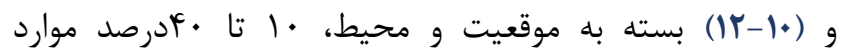

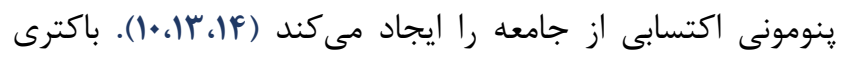
هاى جنس مايكويلاسما فاقد ديواره سلولى هستند و در انسان
عفونت پنومونى آتيبيك ريوى يك عفونت دستخاه تنفسى

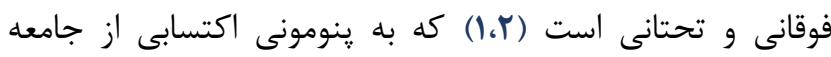
شناخته مىشود (Y) (Community Acquired Pneumonia) سبب التهاب برگشتيذير برونشها مىشود (F). بيماران معمولا

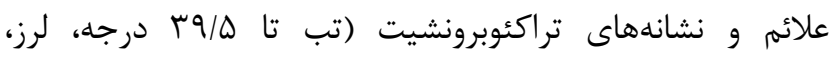
بدحالى، كلودرد، آبريزش از بينى، سردرد و سرفههاى خشك) را

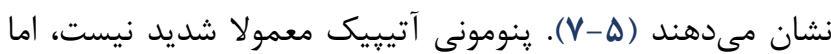


حساسى همانند روشهاى مولكولى PCR بسيار حائز اهميت است كه به بررسى دقيق ميزان شيوع ينومونى ناشى از ماند مايكو بيلاسما

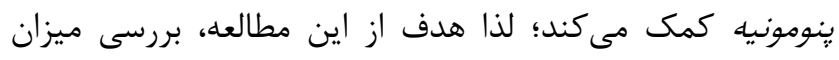

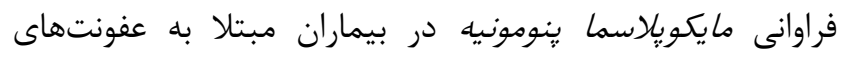
تنفسى مراجعهكننده به بيمارستانهاى مصطفى خمينى (ره) و وانيان

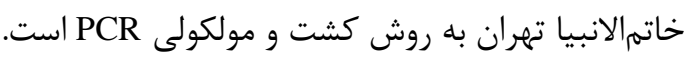

\section{مواد و روشها جمع آورى و كشت نمونهها}

طى اين مطالعه، درمجموع . · انمونه سواب كلو از بيماران

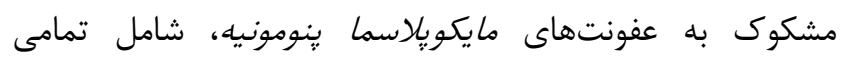

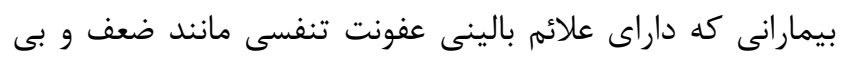

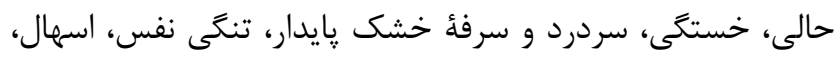

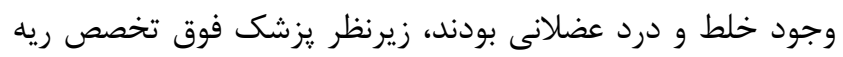

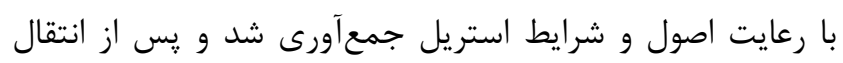

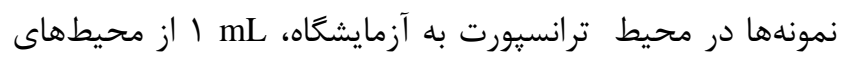

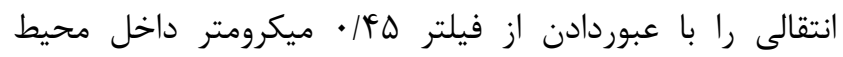

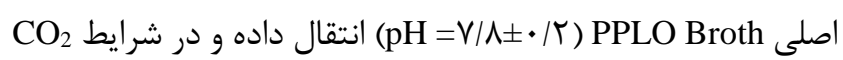

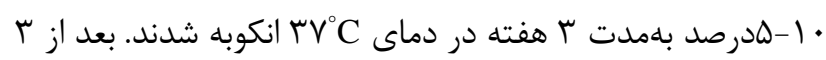

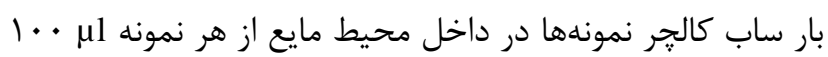

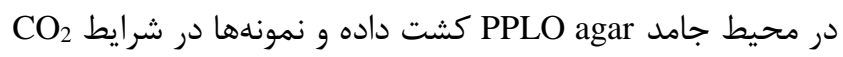

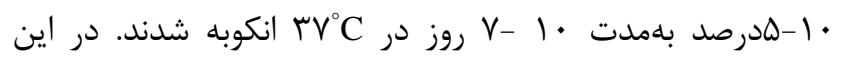

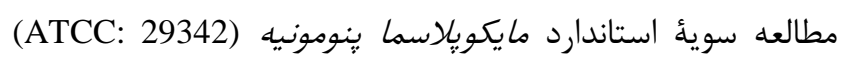

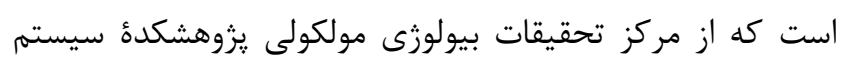

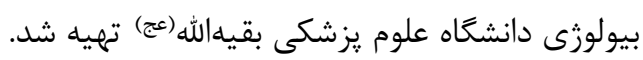

\section{استخراج DNA از نمونهها}

يس از كشت نمونههاى بالينى در محيط مايع PPLO broth

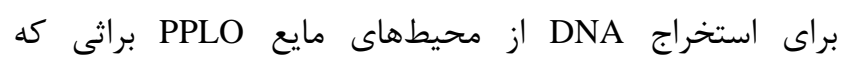

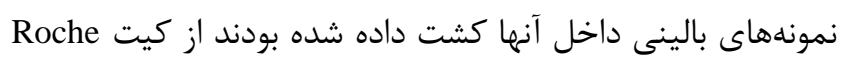

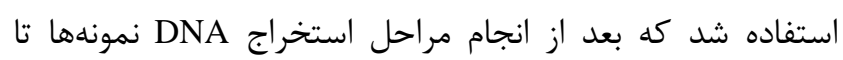

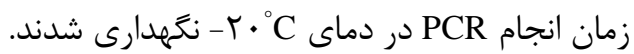

\section{راهاندازى روش مولكولى}

براى شناسايى جنس مايكويلاسما ( زن-16SrRNA) از يرايمرهاى RP:5' و اختصاصى FP: 5' -ACTCCTACGGGAGGCAGCAGT-3 bp) با طول قطعه TGCACCATCTGTCACTCTGTTAACCTC-3

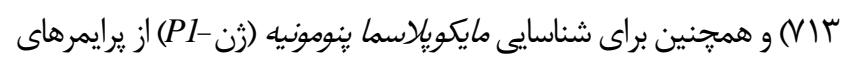

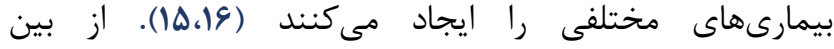

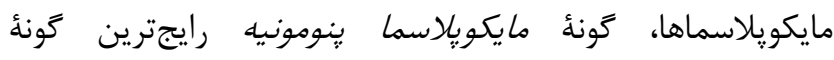

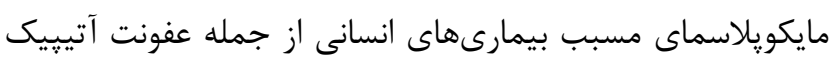

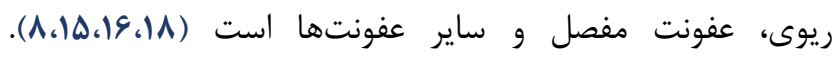

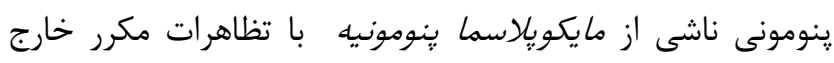

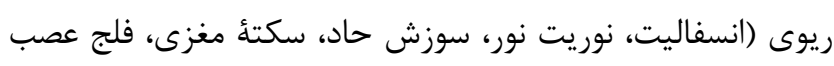

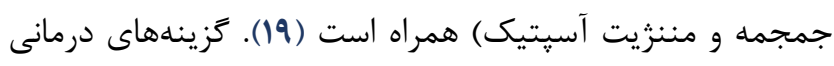

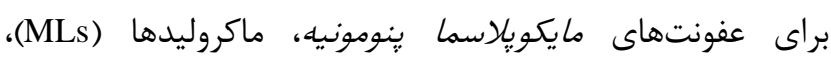

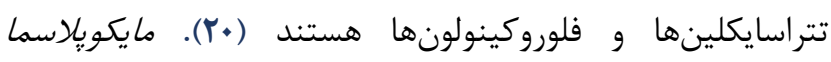

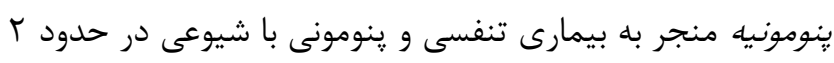

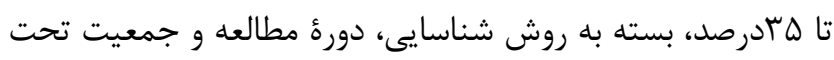

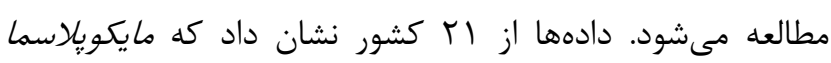

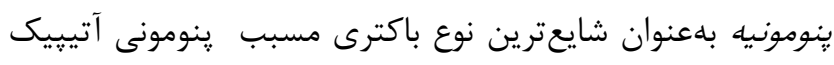

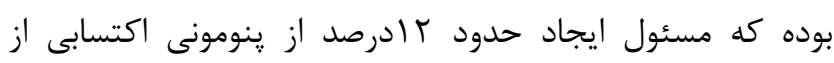

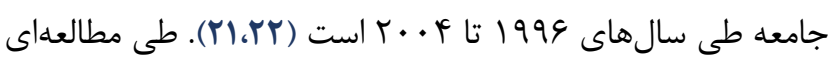

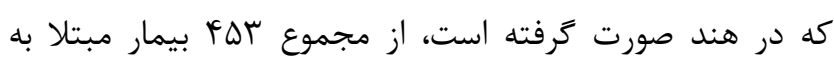

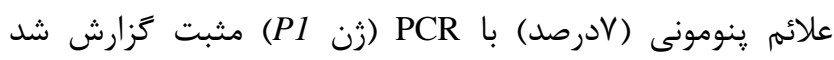

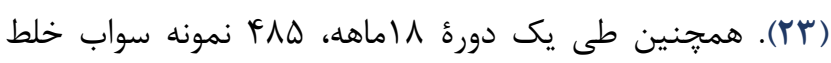

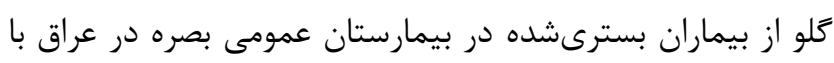

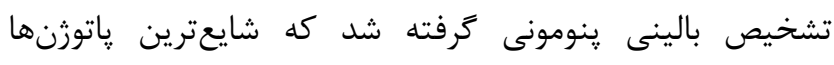
Streptococcus pneumoniae

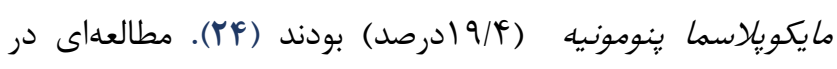

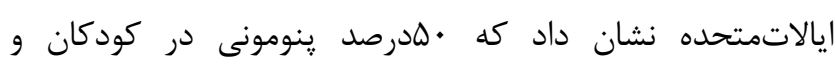

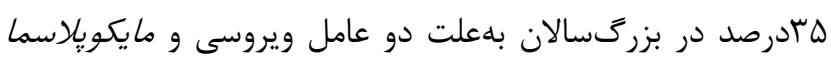

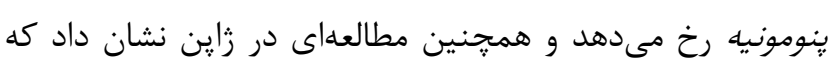

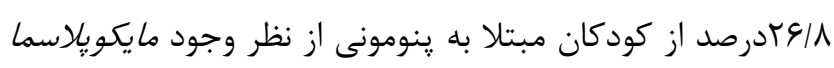

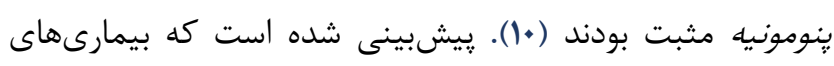

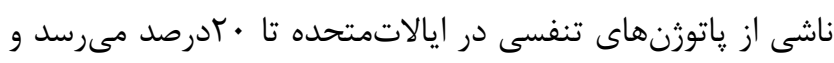

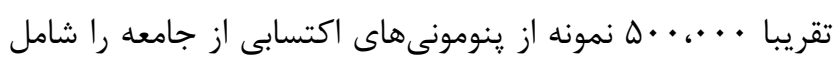

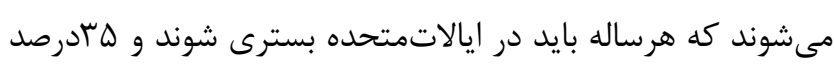

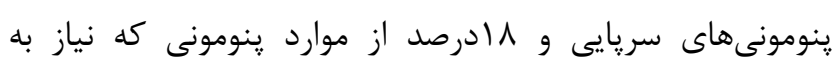

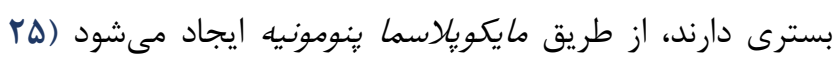

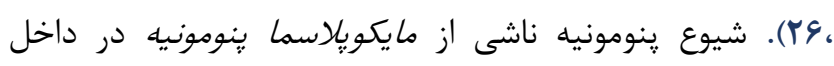

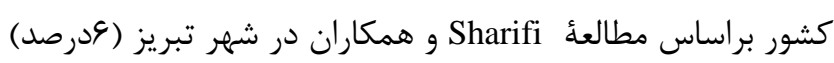

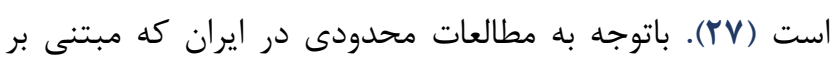

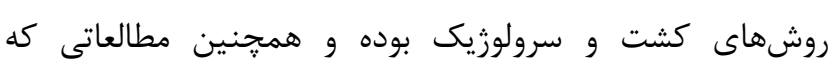

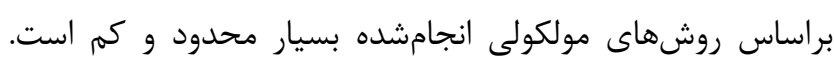

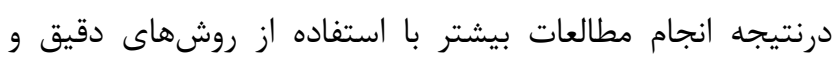




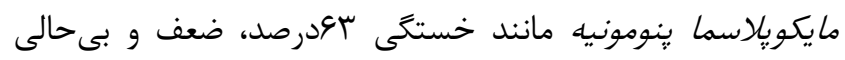

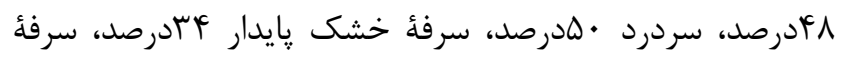
خلطدار اعدرصد، تهوع و استفراغ الrدرصد بودند. تمام بيمارانى

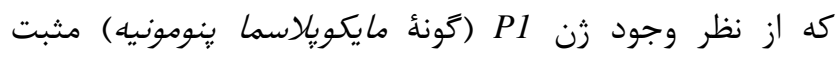
كزارش شدند، داراى اين تظاهرات بالينى بودند.

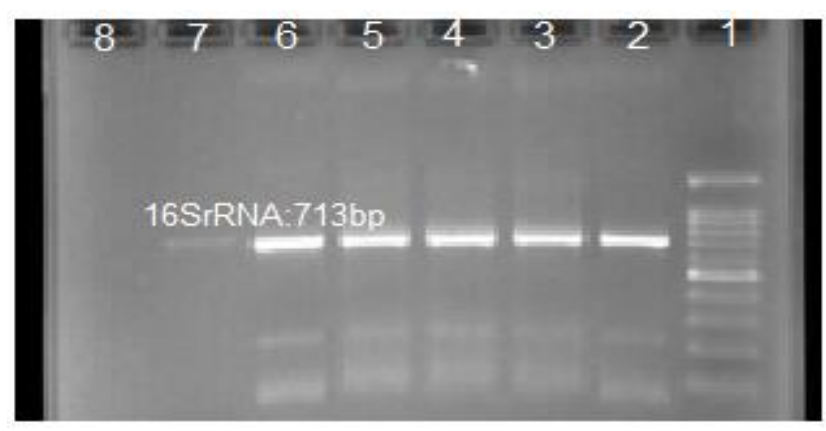

شكل r. نتيجه آزمون PCR براى جنس مايكويلاسما - رن 16SrRNA :

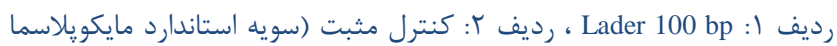

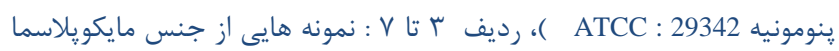
جدا شده از بيمار ان، رديف 1 : كنترل منفى مى باشند.

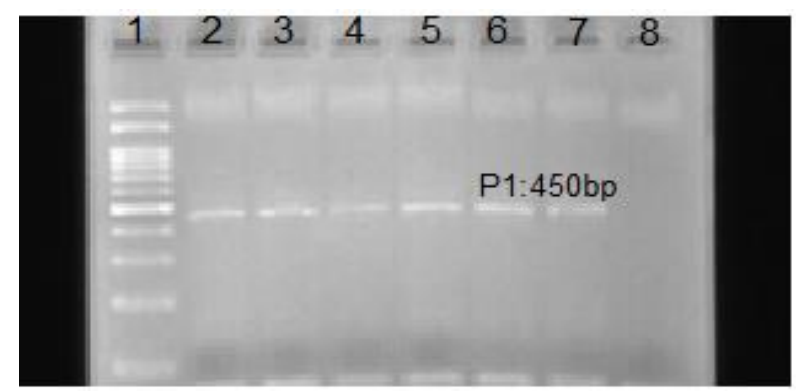

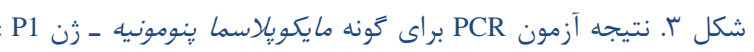

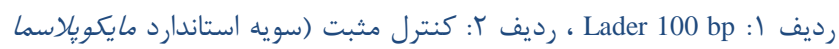

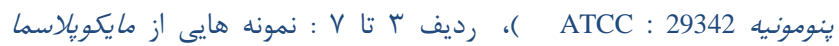

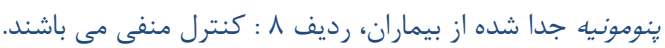

\section{نتايج تعيين توالى محصول PCR زن P1 كونة}

\section{ما يكوبِلاسما بنومونيه}

محصول PCR مربوط به زن P1 گونهُ مايكويلاسما بنومونيه

براى تعيين توالى به يك شركت معتبر در خارج از كشور ارسال

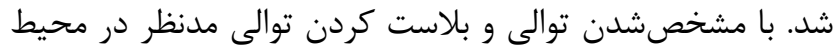
NCBI مايكويالاسما ينومونيه با شباهتى بيش از شكل أ نشان داده شده است.
RP: و' FP: 5'- AAAGGAAGCTGACTCCGACA-3 اختصاصى

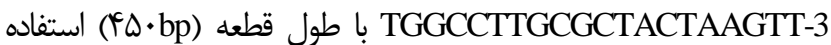

شد (19).

يس از BLAST كردن يرايمرهاى انتخابشده، حساسيت و

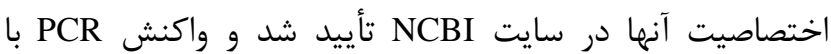
حجم نهايى

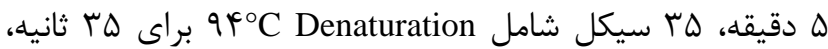

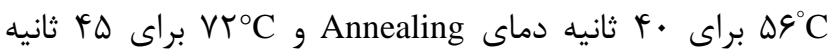
دماى Extension و همجنين يك مرحله Final Extention در

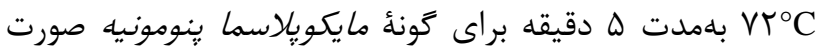

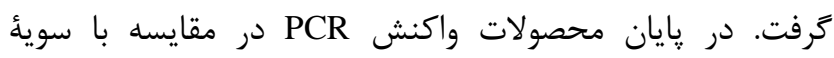

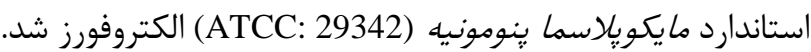

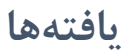

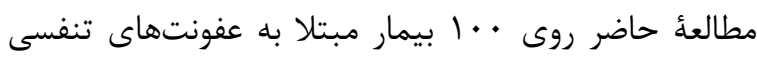

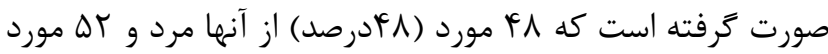

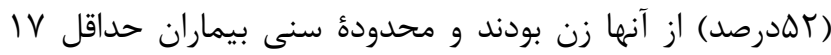

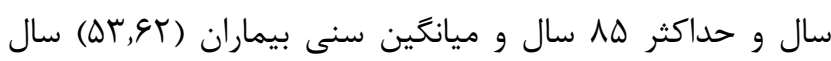
بود. نتايج مطالعة حاضر مشخص كرد كه از نمونههاى جمعآورى لران

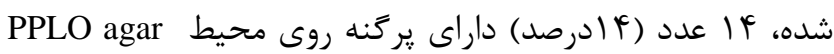
هستند كه در شكل ا نشان داده شده است.

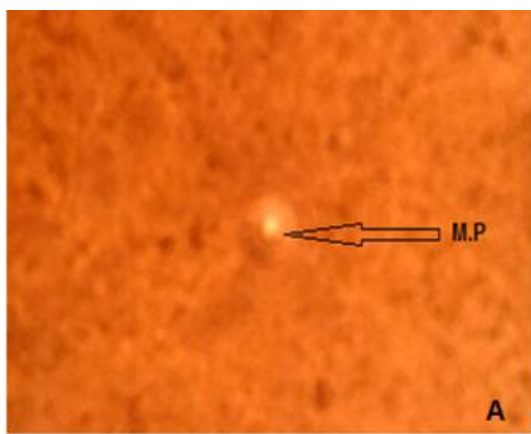

شكل ا. تصوير مربوط به يرَّنه ما يكويلاسما ينومونيه

نتايج راهاندازى PCR براى تشخيص كَونهُ ما يكويلاسما

ينومونيه

نتايج PCR براى تعداد . . ا نمونهُ بالينى سواب علو نشان

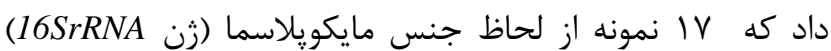
مثبت بوده و 9 نمونه داراى (رن P1) ما يكويلاسما ينومونيه بودند كه در شكل r و ץ نشان داده شده است. همجٍنين در اين مطالعه، حدود نيمى از بيماران داراى تظاهرات بالينى عفونت تنفئ داده 

$\begin{array}{lllll}\text { File: } 55 \text { _p_F.abI } & \text { Run Ended: 2018/1/29 21:8:25 Signal G:789 A:1142 C:1866 T:1325 } & \\ \text { Sample: } 55 \text { _P_F } & \text { Lane: } 41 & \text { Base spacing: 17.412477 } 770 \text { bases in } 16005 \text { scans } & \text { Page 1 of } 2\end{array}$

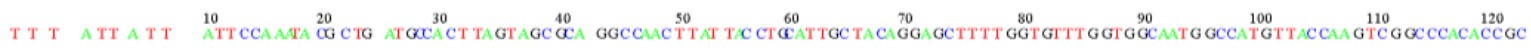

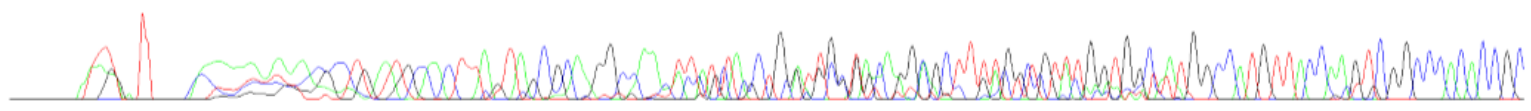

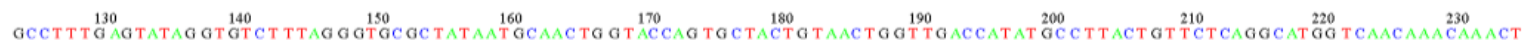

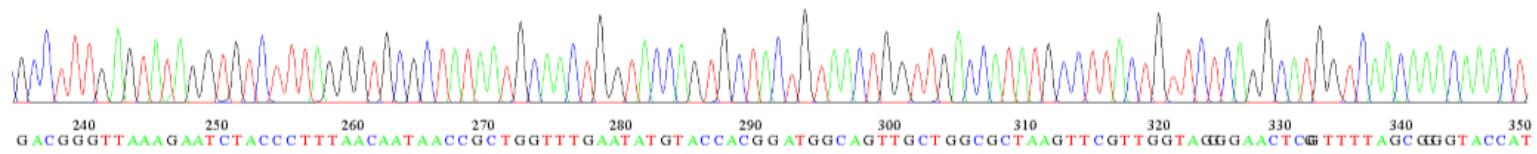

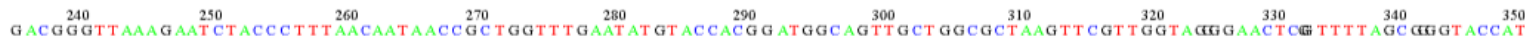

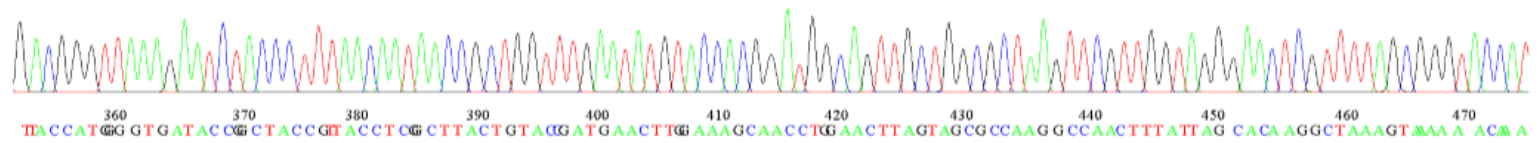

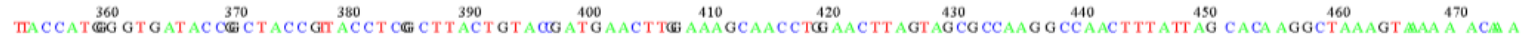

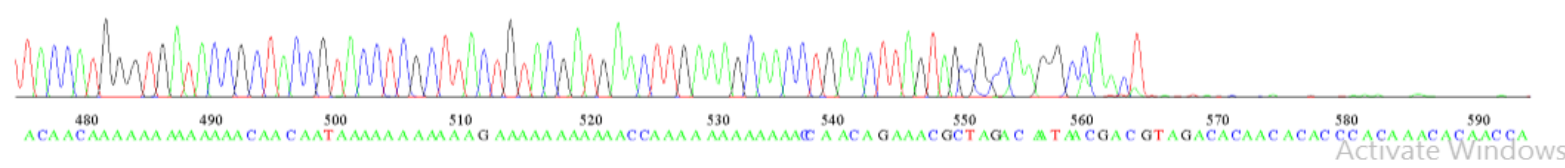

شكل f. توالى حاصل از تعيين توالى محصول PCR زن P1 كونه ما يكوياسما بنومونيه

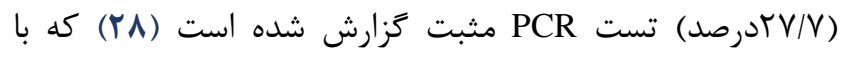

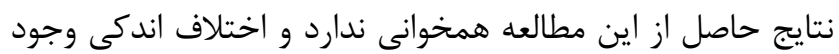
دارد. در مطالعه Wenti Xu و همكاران، اطلاعات اولئ بيماران همراه با نمونهٔ SARI (severe acute respiratory infection) كلو يا سرم جمعآورى شد. هله نمونه SARI جمع آورى شد كه ميزان شيوع عفونت ينومونى ناشى از مايكويلاسما ينومونيه طي إنى

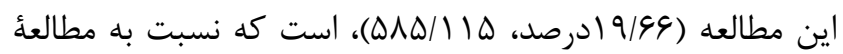

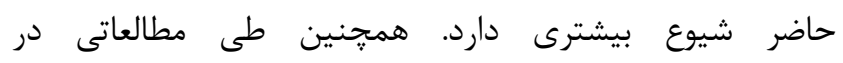

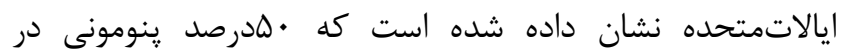

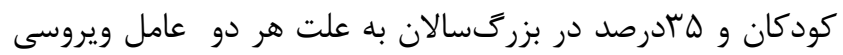

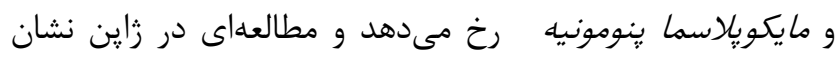

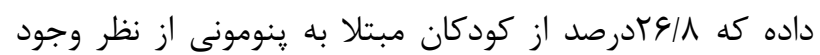

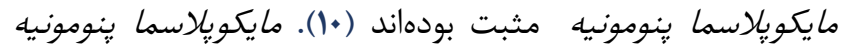

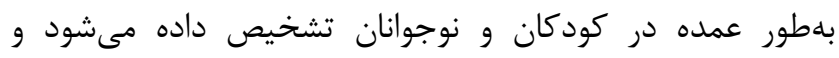

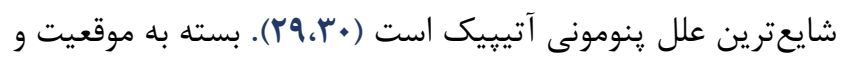

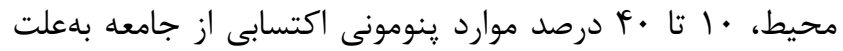

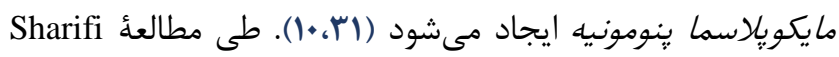

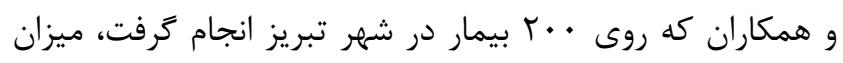

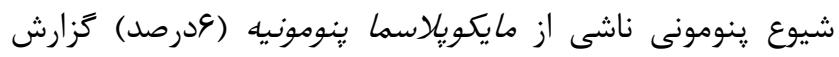

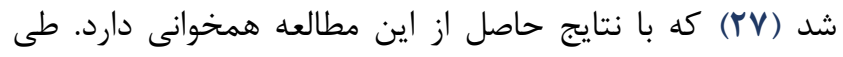

\section{بحث و نتيجه كيرى}

مايكويلاسما بنومونيه يك باكترى منحصربهفرد است كه

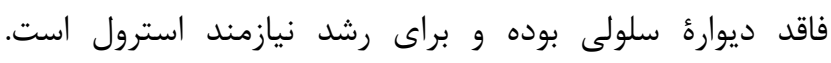

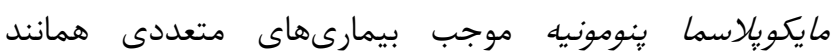
عفونتهاى دستگاه تنفسى (ينومونى آتيييك) مىشود و اين موجب شده است كه مايكويلاسما بنومونيه در كانون توجه قرارئ

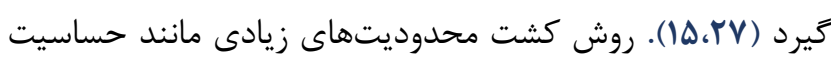
يايين، مدتزمان لازم طولانى براى كشت و از طرفى نياز به

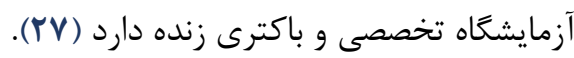

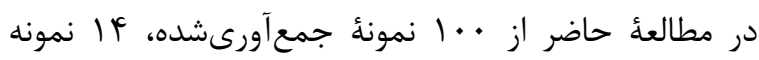

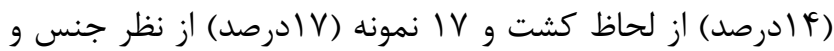

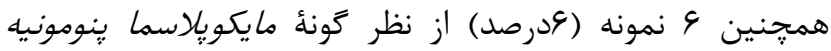

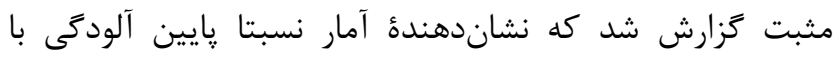

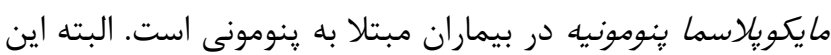

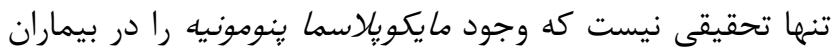

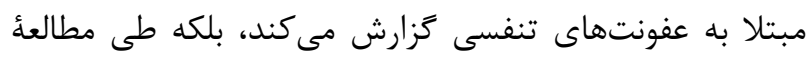
Dash

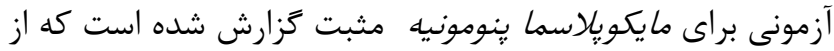

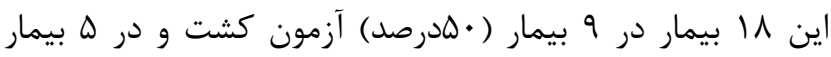


مربوط به گونهُ مايكوِإسما بنومونيه (ودرصد) را در بيماران مبتلا به عفونتهاى تنفسى با سرعت و دقت تشخيص داده و اين نتايج

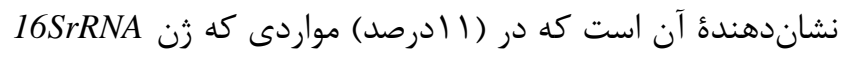
در آنها وجود داشته، زونههاى مربوطه نامشخص هستند و و اين حاكى از آن است كه علاوه بر گونهُ مايكوِلاسما بنومونيه، ديخر كونههاى مايكويلاسما در دستخاه تنفسى حضور دارند كه بايد شناسايى شده و در كانون توجه قرار گيرند. نكتهٔ ديگرى كه اهميت فراوانى دارد، اين است كه براساس نتايج بهدستآمده از

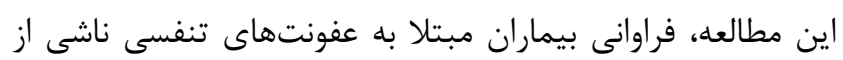

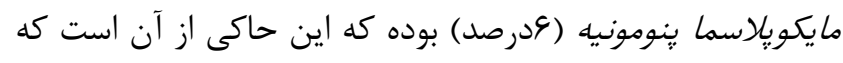

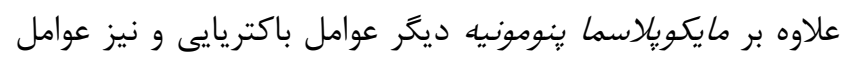

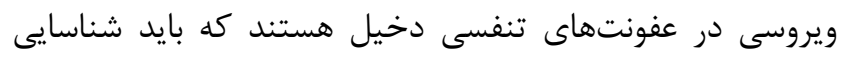

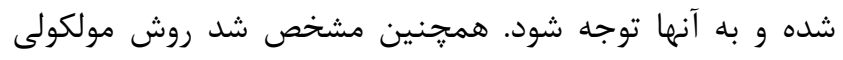
يك تكنيك سريع و حساس براى تشخيص مايكويلاسما

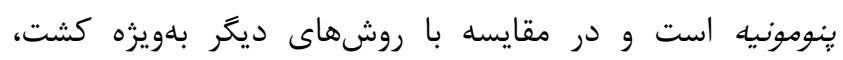

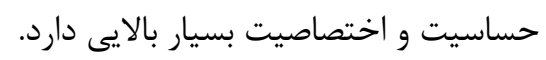
سياسگز ارى

نويسندكان از جناب آقاى دكتر رضا گل محمدى، بهخاطر

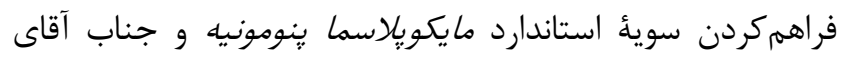
دكتر محمود امين مرعشى و تمام كسانى كه ما را در اين راه يارى كردند، تشكر و قدردانى مى كنند. تعارض منافع بين نويسندكان تعارض در منافع گزارش نشده است.

\section{References}

1. Amirian S, Amini K, Parviz M. Identification of Mycoplasma Pneumonia Isolated from the Respiratory Secree tions of Patients with Chronic Obstructive Pulmonary Disease Using Polymerase Chain Reaction in Kerman Province, Iran. Tabari J Prev Med. Winter 2016; 1(3): 8-15.

2. Gdalevich M, Haas EJ, Dukhan L, Katz M, Zelenski V, Moran-Gilad J. control of a Mycoplasma pneumoniae Outbreak in an institutional setting Using azithromycin Prophylaxis. Frontiers in public health. 2018; 5: 366. https://doi.org/10.3389/fpubh.2017.00366

3. Li W, Fang YH, Shen HQ, Yang DH, Shu Q, Shang SQ. Evaluation of a real-time method of simultaneous amplification and testing in diagnosis of Mycoplasma pneumoniae infection in children with pneumonia.
مطالعات صورتگرفته، شيوع عفونت ينومونى ناشى مايكوِّاسما

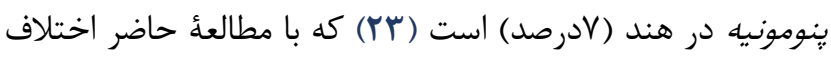
اندكى دارد. طبق تحقيقاتى كه در كشورهاى ديگر انجام شده،

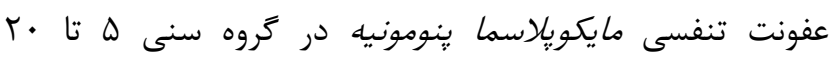

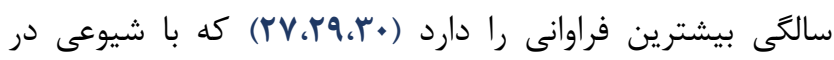
حدود r تا ها درصد و بسته به روش شناسايى، دوره مطالعه و

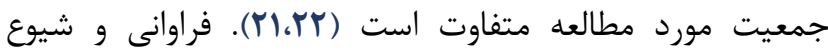

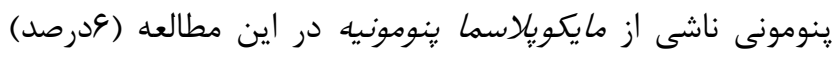

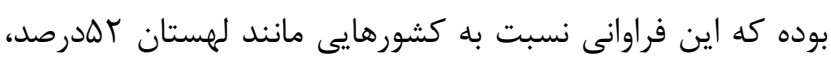

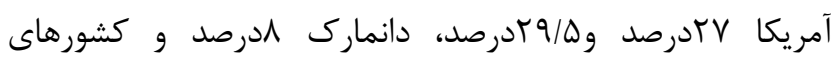

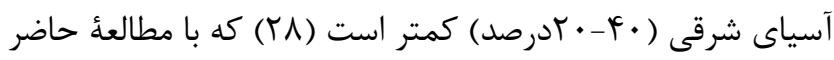
همخوانى ندارد. فراوانى عفونت ڤينومونى ناشى از مايكويلاسما

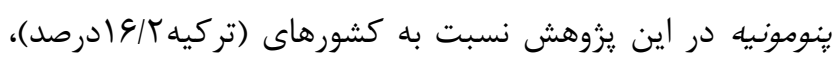

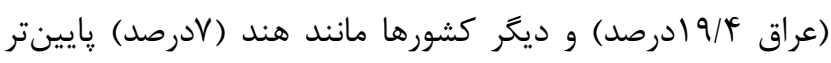

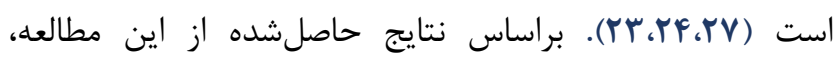
فراوانى اين عفونت نسبت به شهر اهواز (سادرصد) و شهر رشت (ادرصد) بالاتر است و با فراوانى آن در شهر تبريز برابر است آنوان (TV)

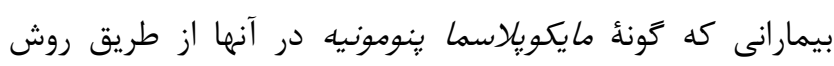
مولكولى PCR مثبت شدند، داراى علائم بالينى عفونت تنفسى لئى مانند (ضعف و بى حالى، خستكى، سردرد و سرفئ خشك يايدار،

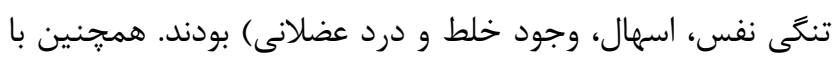

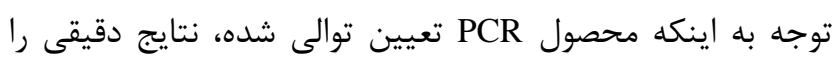

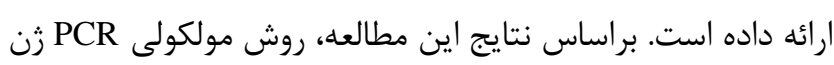
16SrRNA

PloS one. 2017; 12(5): e0177842. https://doi.org/10.1371/journal.pone.0177842

4. Wang L, Feng Z, Zhao M, Yang S, Yan X, Guo W, et al. A comparison study between GeXP-based multiplex-PCR and serology assay for Mycoplasma pneumoniae detection in children with community acquired pneumonia. BMC Infect Dis. 2017; 17(1): 518. https://doi.org/10.1186/s12879-017-2614-3

5. Topley and wilson's microbiology and microbial infections( 10th edition ) W.G.Mertz, R.J.Hay.London. Hodder Arnold.2017 .

6. Kheiri B, Alhesan NA, Madala S, Assasa O, Shen M, Dawood T. Mycoplasma pneumoniae-associated Fuchs syndrome. Clinical case reports. 2018; 6(2): 434. https://doi.org/10.1002/ccr3.1350 
7. Yu Y, Fei A. Atypical pathogen infection in community-acquired pneumonia. Biosci Trends. 2016; 10(1): 7-13. https://doi.org/10.5582/bst.2016.01021

8. Mahon CR, Lehman DC, Manuselis G. Textbook of diagnostic microbiology-e-Book. Elsevier Health Sciences; 2014.

9. Sharma L, Losier A, Tolbert T, Cruz CS, Marion CR. Pneumonia updates on Legionella, Chlamydophila, and Mycoplasma pneumonia. Clinics in chest medicine. 2017; $\quad 38(1)$ : 45. https://doi.org/10.1016/j.ccm.2016.11.011

10. Xu W, Guo L, Dong X, Li X, Zhou P, Ni Q, et al. Detection of Viruses and Mycoplasma pneumoniae in Hospitalized Patients with Severe Acute Respiratory Infection in Northern China, 2015-2016. Jpn J Infect Dis. 2018 ; $\quad 71(2): \quad 134 \quad$ - 9. https://doi.org/10.7883/yoken.JJID.2017.412

11. Bao YX, Li J, Tian Y, Liu QH, Bao J. Atopy: a risk factor of refractory mycoplasma pneumoniae pneumonia?. Clin Respir J. 2017; 11(6): 931-4. https://doi.org/10.1111/crj.12439

12. Wang ZH, Li XM, Wang YS, Guo ZY. Changes in the levels of interleukin-17 between atopic and non-atopic children with Mycoplasma pneumoniae pneumonia. Inflammation. 2016; 39(6): 1871-5. https://doi.org/10.1007/s10753-016-0422-3

13. Kim JH, Cho TS, Moon JH, Kim CR, Oh JW. Serial changes in serum eosinophil-associated mediators between atopic and non-atopic children after Mycoplasma pneumoniae pneumonia. Allergy Asthma Immunol Res. 2014; 6(5): 428-33. https://doi.org/10.4168/aair.2014.6.5.428

14. Dorairaj A, Kopula SS, Kumar K. Atypical Pneumonia-Screening in a Tertiary Care Centre. J Clin Diagn Res. 2015; 9(11): DC18.

15. Golmohammadi R, Ataee RA, Alishiri GH, Mirnejad $\mathrm{R}$, Najafi A, Tate $\mathrm{M}$, et al. Molecular diagnosis of Mycoplasma pneumoniae in synovial fluid of rheumatoid arthritis patients. Iran J Med Microbiol. 2014; 8(1): 1-8.

16. Page CA, Krause DC. Protein kinase/phosphatase function correlates with gliding motility in Mycoplasma pneumoniae. Journal of bacteriology. 2013; 195(8): 1750-7. https://doi.org/10.1128/JB.02277-12

17. Kawai Y, Miyashita N, Kubo M, Akaike H, Kato A, Nishizawa $Y$, et al. Nationwide surveillance of macrolide-resistant Mycoplasma pneumoniae infection in pediatric patients. Antimicrobial agents and chemotherapy. 2013; 57(8): 4046-9. https://doi.org/10.1128/AAC.00663-13

18. Tian XJ, Dong YQ, Dong XP, Li JY, Li D, Jiang Y, et al . P1 gene of Mycoplasma pneumoniae in clinical isolates collected in Beijing in 2010 and relationship between genotyping and macrolide resistance. Chinese Medical Journal. 2013; 126 (20): 3944-3947.

19. Cillóniz C, Torres A, Niederman M, van der Eerden M, Chalmers J, Welte T, Blasi F. Community-acquired pneumonia related to intracellular pathogens. Intensive care medicine. 2016; 42(9): 1374-86. https://doi.org/10.1007/s00134-016-4394-4

20. Spuesens EB, Meijer A, Bierschenk D, Hoogenboezem T, Donker GA, Hartwig NG, et al. Macrolide resistance determination and molecular typing of Mycoplasma pneumoniae in respiratory specimens collected between 1997 and 2008 in The Netherlands. Journal of clinical microbiology. 2012; 50(6): 1999-2004. https://doi.org/10.1128/JCM.00400-12

21. Meyer Sauteur PM, Unger WW, Nadal D, Berger C, Vink C, van Rossum A. Infection with and Carriage of Mycoplasma pneumoniae in Children. Front Microbiol. 2016; 7: 329.https://doi.org/10.3389/fmicb.2016.00329

22. Carrim M, Wolter N, Benitez AJ, Tempia S, du Plessis M, Walaza S, et al. Epidemiology and Molecular Identification and Characterization of Mycoplasma pneumoniae, South Africa, 2012-2015. Emerging infectious diseases. 2018; 24(3): 506. https://doi.org/10.3201/eid2403.162052

23. Chaudhry R, Valavane A, Sreenath K, Choudhary M, Sagar T, Shende T, et al. Detection of Mycoplasma pneumoniae and Legionella pneumophila in Patients Having Community-Acquired Pneumonia: A Multicentric Study from New Delhi, India. Am J Trop Med Hyg. 2017; 97(6): 1710-6. https://doi.org/10.4269/ajtmh.17-0249

24. Al-Ghizawi GJ, Al-Sulami AA, Al-Taher SS. Profile of community- and hospital-acquired pneumonia cases admitted to Basra General Hospital, Iraq. East Mediterr Health J. 2007; 13(2): 230-42.

25. Talkington DF, Thacker WL, Keller DW, Jensen JS. Diagnosis of Mycoplasma pneumoniaeInfection in Autopsy and Open-Lung Biopsy Tissues by Nested PCR. Journal of clinical microbiology. 1998; 36(4): 1151-3.

26. Zhang Y, Mei S, Zhou Y, Yang D, Pan T, Chen Z, Wang Q. TIPE2 negatively regulates mycoplasma pneumonia-triggered immune response via MAPK signaling pathway. Scientific reports. 2017; 7(1): 13319.

27. Sharifi S, Ghotaslo R, Aki MT, Soroush MH, Ansarian $\mathrm{Kh}$, Shabanpour J, et al. Identification of respiratory infections caused by Mycoplasma pneumoniae With three methods of cultivation, ELISA and PCR . Medical journal of Tabriz University. 2011; 33(3): 3641.

28. Dash S, Chaudhry R, Dhawan B, Dey AB, Kabra SK, Das BK. Clinical spectrum and diagnostic yields of 


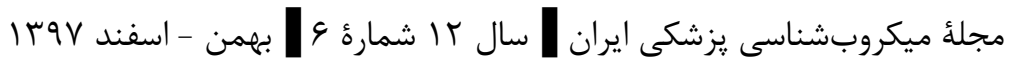

Mycoplasma pneumoniae as a causative agent of community-acquired pneumonia. J Lab Physicians. 2018; 10(1): 44-49.

https://doi.org/10.4103/JLP.JLP_62_17

29. Zhou Y, Zhang Y, Sheng Y, Zhang L, Shen Z, Chen Z. More complications occur in macrolide-resistant than in macrolide-sensitive Mycoplasma pneumoniae pneumonia. Antimicrobial agents and chemotherapy. 2014; 58(2): 1034-8.

https://doi.org/10.1128/AAC.01806-13

30. Morozumi M, Hasegawa K, Kobayashi R, Inoue N, Iwata $\mathrm{S}$, Kuroki $\mathrm{H}$, et al. Emergence of macrolideresistant Mycoplasma pneumoniae with a 23S rRNA gene mutation. Antimicrobial agents and chemotherapy. 2005; 49(6): 2302-6.

https://doi.org/10.1128/AAC.49.6.2302-2306.2005

31. Xiao L, Ptacek T, Osborne JD, Crabb DM, Simmons WL, Lefkowitz EJ, et al. Comparative genome analysis of Mycoplasma pneumoniae. BMC Genomics. 2015; 16(1): 610. https://doi.org/10.1186/s12864-015-1801-0 